\title{
Chapter Four
}

\section{Decentralisation, Forests and Estate Crops in Kutai Barat District, East Kalimantan ${ }^{1}$}

\author{
Anne Casson
}

\section{Introduction}

This chapter examines the initial impacts of decentralisation on forests and estate crops in the district of Kutai Barat, East Kalimantan. It is one of nine district-level case studies carried out during 2000 and early 2001 by the Centre for International Forestry Research (CIFOR) in four provinces: Riau, East Kalimantan, Central Kalimantan, and West Kalimantan. Fieldwork for this study was conducted in mid-2000 and the author has relied on secondary material and key informants to update some information.

Located in the upper region of East Kalimantan's Mahakam river basin, West Kutai district was formed through the administrative division of the previous Kutai district shortly after the Habibie government issued Law No. 22/1999 and Law No. 25/1999 on the decentralisation of authority from the central government to district governments. As a newly formed district, Kutai Barat had limited infrastructure and revenue. Local government officials also had limited capacity to develop policy and sustainably manage natural resources.

Decentralisation did, nevertheless, provide opportunities for the government of Kutai Barat to secure a greater portion of the revenues generated by forests and mineral resources extracted within the district; and to build up the district's physical infrastructure and industrial facilities. In 2000, the Kutai Barat district government issued large numbers of small-scale timber extraction licenses,

\footnotetext{
1 Research for this chapter was supported by the Centre for International Forestry Research, the Australian Centre for International Agricultural Research and the United Kingdom's Department for International Development. The opinions expressed here are the views of the author and do not necessarily represent the official policies of any of these organisations. The research itself was supported and informed by the following people in East Kalimantan, Jakarta and Bogor: Anja Hoffmann, Ben Santoso, Eric Wakker, Frank Flashe, Gottfried von Gemmingen, Grahame Usher, Hans Beukeboom, Hery Romadan, Kadok, Liz Chidley, Neil Scotland, Rudi Ranaq, Rona Dennis, the staff of BIOMA, and all of the local inhabitants of Kutai Barat who gave their time while I was in the area. During the time of writing, additional support and encouragement was provided by Carol Colfer, Chris Ballard, Colin Filer, Ketut Deddy, Hidayat Al-Hamid, Peter Kanowski, Stephen Midgley, Yvonne Byron, Chris Barr, Daju Pradnja Resosudarmo, John McCarthy, Lesley Potter and Simon Badcock. Finally, I would like to thank Erna Rositah (BIOMA), who accompanied me in the field for three weeks. With her help and expertise, I learned a great deal and had many an adventure.
} 
known as Hak Pemungutan Hasil Hutan (HPHH) permits, to establish a district regulatory regime for forest exploitation. The district government also indicated that it would encourage investors in the oil palm industry to establish operations in Kutai Barat. The HPHH scheme resulted in widespread and accelerated deforestation in the district and attracted considerable criticism from a wide range of stakeholders, including NGOs, donors, provincial governments and the forest industry. The district government eventually heeded these concerns and set about establishing a more equitable and sustainable forest regime, which seeks to facilitate local development.

\section{Kutai Barat and Its Resources}

\section{Geography}

Kutai Barat is one of the newly formed districts (kabupaten) in East Kalimantan. It was officially established in November 1999, in accordance with Law No. 47/1999, which outlined the division of the original kabupaten of Kutai ${ }^{2}$ into three districts: Kutai Barat, Kutai Timur and Kutai Kartanegara ${ }^{3}$ (Figure 4.1). Before Kutai was divided into three smaller kabupaten, it was the largest district in East Kalimantan, covering 94629 square kilometres $\left(\mathrm{km}^{2}\right)$, or approximately 46 per cent of the province's total land area (BAPPEDA and BPS 1998). Kutai also had a long history as an administrative unit, having originated from the Kutai sultanate established late in the $15^{\text {th }}$ century along the Mahakam River (Magenda 1991).

The decision to divide Kutai into three districts was long awaited, as the sheer size of the original district made it difficult to administer. Indeed, several remote areas, which now primarily lie within Kutai Barat, have limited physical infrastructure and industrial facilities due in part to their isolation from the former district's administrative centre. Moreover, the division followed the release of Indonesia's regional autonomy laws (No. 22/1999 and No. 25/1999), which ostensibly aimed to provide an opportunity for further autonomy in the region and to allow local governments to be more responsive to local communities (Bupati Kutai 2000).

\footnotetext{
2 Kutai was established as a kabupaten in 1959 with the enactment of Law No. 27/1959 concerning the formation of Daerah Tingkat II in East Kalimantan. The first Regent of Kutai was A.R. Padmo.

3 When I visited Kutai Barat in July 2000, Kutai Kartanegara was referred to as Kutai Induk, meaning the 'mother' district. However, the people and government of this district now prefer to call it Kutai Kartanegara. This term is therefore used throughout this chapter.
} 


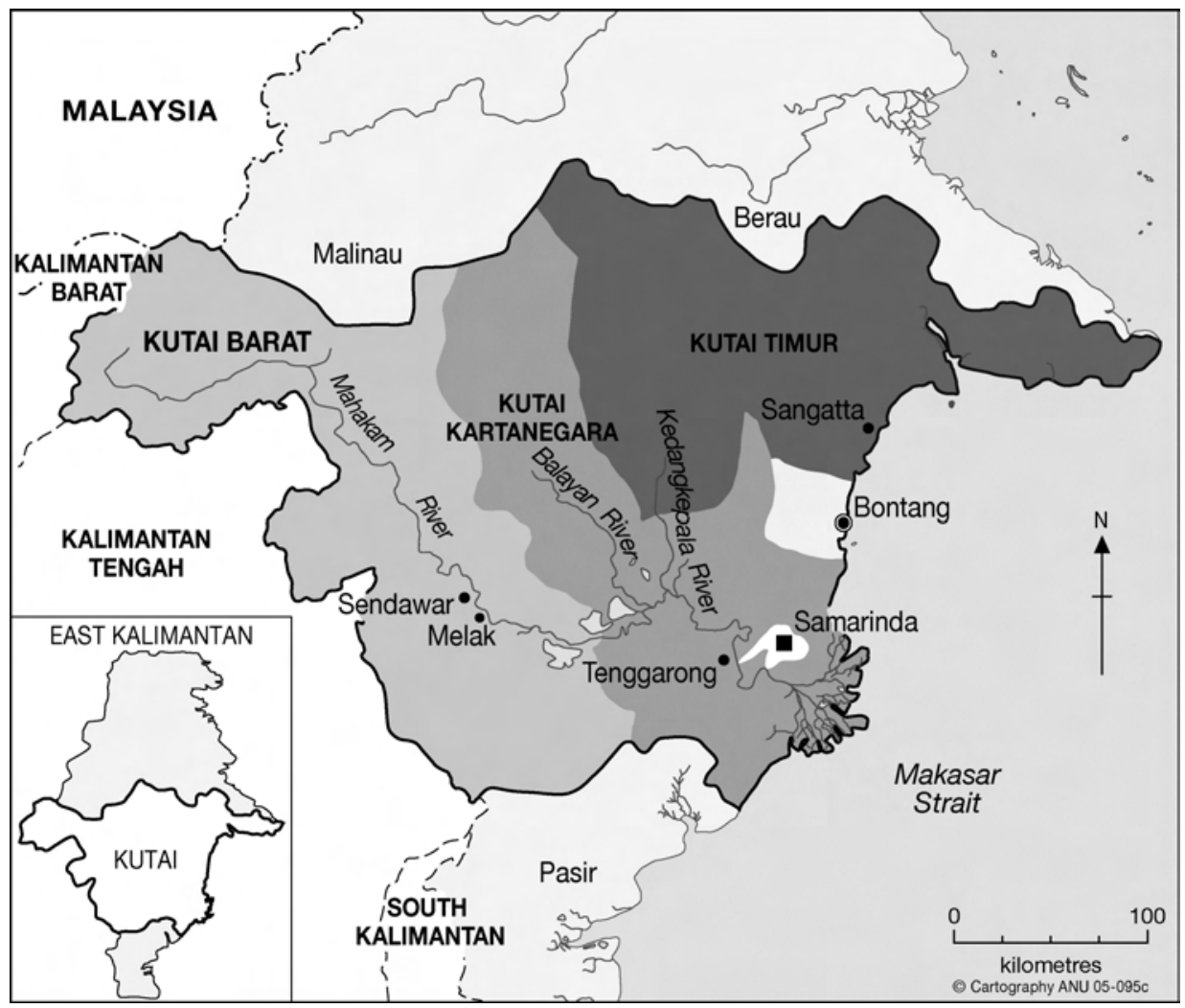

Figure 4.1. Kutai Region, East Kalimantan

Source: Map data from GTZ Sustainable Forest Management Project

Kutai Barat now spans an area of approximately $32000 \mathrm{~km}^{2}$, or 16 per cent of East Kalimantan's total land area. It is located in the western part of the province and borders both Central and West Kalimantan, as well as the East Malaysian state of Sarawak. The newly formed district consisted of 14 sub-districts (kecamatan), 205 villages and approximately 150000 people in $2000^{4}$ (Figure 4.2). The capital of Kutai Barat is Sendawar, but all of the existing government offices were located within the town of Melak. When fieldwork was undertaken in July 2000, Kutai Barat had a temporary Bupati, or district head, named Bp. Rama Alexander Asia. He had the difficult job of forming a new district government and legislative assembly without having full authority and legitimacy to rule. He was formally elected in March 2000 and the district legislative assembly was elected in December 2000.

${ }^{4}$ Statistics vary on the actual area and population of Kutai Barat. According to the Regional Development Planning Agency (BAPPEDA and BPS 1998), the area of Kutai Barat is $33118 \mathrm{~km}^{2}$ and the population is 122 153. However, Bupati Kutai (2000) claims that the area is $31628 \mathrm{~km}^{2}$ and the population is 150871. 


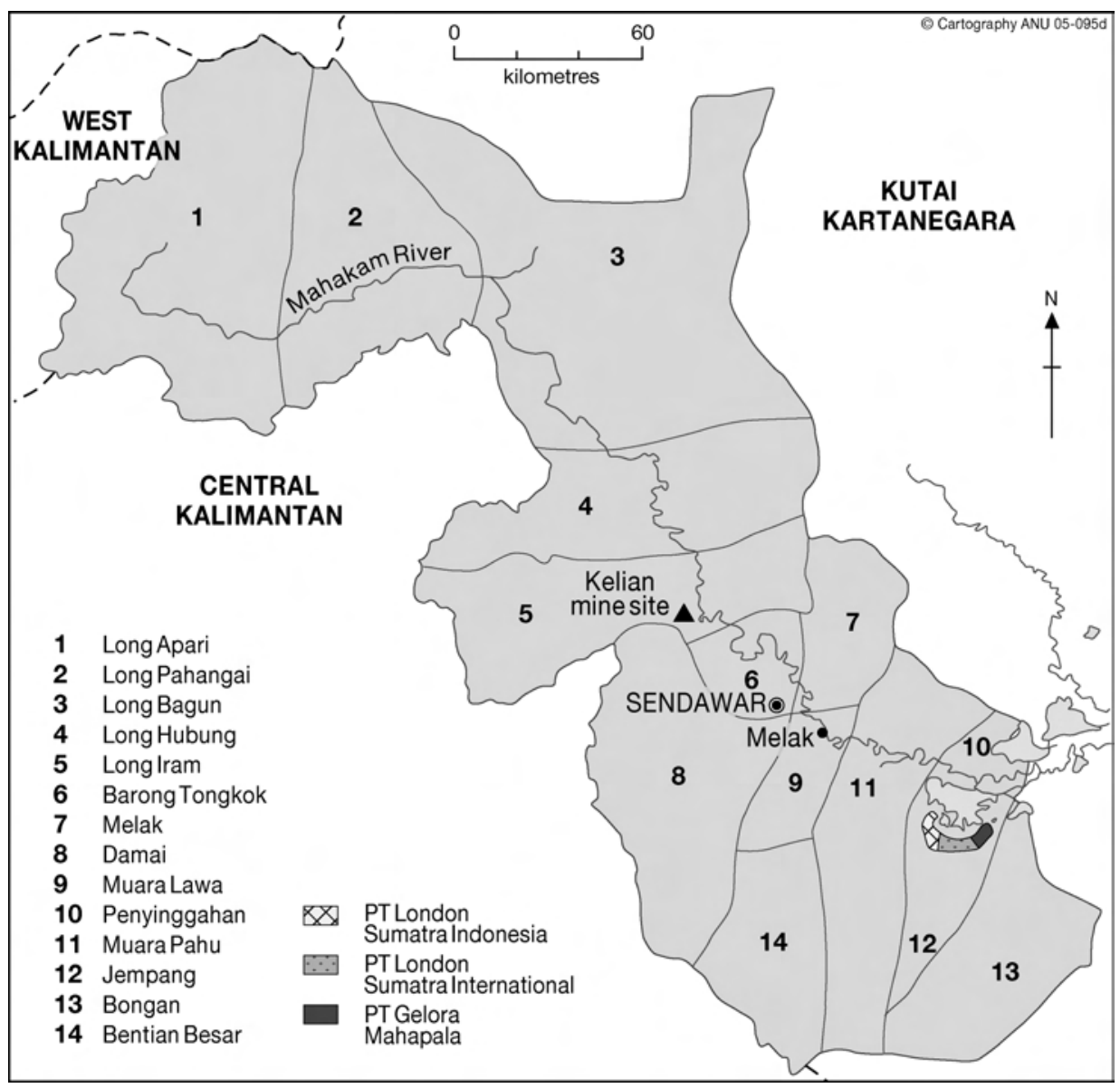

Figure 4.2. Kutai Barat District, East Kalimatan

Source: Map data from GTZ Sustainable Forest Management Project

\section{Economy}

Most of the physical infrastructure and industrial facilities established in the original district of Kutai are now located within the jurisdiction of a newly formed district now known as Kutai Kartanegara. This meant that Kutai Barat had fairly limited infrastructure, but perhaps no more so than some of the other newly formed districts in East Kalimantan, such as Malinau or Nunukan. It was also quite isolated. To get to Kutai Barat one had to catch a boat from Samarinda up the Mahakam River. Depending on the boat, the trip took anywhere between eight and 24 hours. There was one asphalt road in Melak that was $25 \mathrm{~km}$ long. The rest of the roads were dirt roads and almost impassable during the wet season. In fact, five sub-districts (Long Apari, Long Pahangai, Long Bagun, Long Hubung and Penyinggahan) could not be reached by road in 2000. 
Government offices in Kutai Barat also had limited facilities and were poorly resourced. ${ }^{5}$ In fact, many offices had not been established when fieldwork for this study was conducted. ${ }^{6}$ By June 2000 , for instance, there was no district government forestry agency, only a branch office of East Kalimantan's Provincial Forestry Service (Cabang Dinas Kehutanan). Public servants working in the district also openly admitted that they were poorly trained and lacked the knowledge required to run a district and develop regional policy (interviews with Kutai Barat government officials, 28 July 2000). The closest university was in Samarinda, and there were just two secondary schools - one in Melak and the other in Long Iram. Other community services in the district were also extremely poor. For instance, there was no hospital and no reliable telephone or electricity supply.

\section{Forest Resources}

Kutai was once covered in dense tropical forest. These forests were described by the Norwegian naturalist and explorer Carl Bock, who was commissioned by the Dutch colonial government in the 1880s to travel halfway up the Mahakam River. In a report on the journey, Bock wrote:

Enormous trees, with massive straight stems rising sixty or eighty feet from the ground before throwing out a single branch, overshadowed the rank vegetation beneath, the thickness of which rendered it impossible to penetrate into the forest more than a few yards from the riverside (Bock 1985: 51).

Since the Suharto government opened up Indonesia's outer island forests to large-scale cutting in the late 1960s, most of the forest described by Bock has been cleared (Bupati Kutai 2000). Potter (1990) estimates that around forty per cent of Indonesia's log production originated from East Kalimantan during the period 1970-79. A large proportion of this timber came from the area now known as Kutai Kartanegara, just west of Kutai Barat, because the largest stands of commercial species, such as meranti, keruing and agathis, could be found there. The Mahakam River also provided a well-developed transport system (Manning 1971).

In addition to the impact of large-scale logging, extensive areas of forest land have been converted to plantations or agriculture (Bupati Kutai 2000). A large proportion of Kutai Kartanegara's forest cover was also severely burnt during

\footnotetext{
${ }^{5}$ It is perhaps interesting to note that most of the office furniture in the Regent's office had been donated by PT Kelian Equatorial Mining, a company mining gold in the area.

6 When I visited in July 2000, the only offices to be found in Melak were: Cabang Dinas Kehutanan (branch office of the Provincial Forestry Service), Dinas Pertanian (District Agriculture Office), BAPPEDA (Regional Planning Agency), Dinas Pendapatan Daerah (District Income Office), Sospol (District Social-Politics Office), Dinas Kesehatan (District Health Office) and Dinas Perkebunan (District Estate Crops Office).
} 
the 1982-83 and 1997-98 forest fires (Brookfield et al. 1995; Hoffmann et al. 1999). In 2000, the landscape consequently bore little resemblance to that described by Bock. Few trees could be seen on a journey up the Mahakam River and large sawmills dominated the landscape between Samarinda and Tenggarong.

Before Kutai was divided into three districts it had 1.8 million hectares (ha) of forest land classified as 'Protected Forest'; 270000 ha of 'Parks and Reserve Forest'; 2.6 million ha of 'Limited Production Forest'; 3.3 million ha of 'Production Forest'; 3.1 million ha of 'Conversion Forest'; and 22724 ha of 'Research Forest' (BAPPEDA and BPS 1998). While these categories do not necessarily correspond with actual forested area, the Forest Land Use Consensus Plan (Tata Guna Hutan Kesepakatan) was developed to show definitive boundaries between the various categories of land under the Forestry Department's control. The plan was revised in the mid-1990s to reconcile provincial and district needs, including a desire to convert production forest to conversion forest in order to facilitate oil palm developments. This revision resulted in the development of Provincial Land Use Plan (Rencana Tata Ruang Wilayah Propinsi) classifications in the mid-1990s. A District Land Use Plan (Rencana Tata Ruang Wilayah Kabupaten) was also drawn up for the original administrative boundary of Kutai, but had not been completed for Kutai Barat when fieldwork for this study was undertaken. However, the district government estimated that approximately 50-60 per cent of Kutai Barat was still forested in 2000 (Bupati Kutai 2000).

Before Kutai was divided into three districts, the Mahakam Ulu branch office of the Provincial Forestry Service monitored forest activities and production in the area now known as Kutai Barat. The forest area monitored by this agency has remained more or less the same since the partition of Kutai. According to its own statistics, the Mahakam Ulu area produced approximately 3 million cubic meters $\left(\mathrm{m}^{3}\right)$ of logs during the period 1994-98. This made the area the fourth largest producer of logs within the province after Mahakam Tengah (now known as Kutai Kartanegara - 7.3 million $\mathrm{m}^{3}$ ), Berau (3.9 million $\left.\mathrm{m}^{3}\right)$, and Bulungan Utara (3.6 million $\mathrm{m}^{3}$ ). According to official statistics, log production in the Mahakam Ulu area had gradually declined between 1995 and 2000 from 818324 $\mathrm{m}^{3}$ in 1994/95 to $619426 \mathrm{~m}^{3}$ in 1998/99 (Kalimantan Timur 1999). However, many suspected that there had been an increase in illegal logging in the area during the same time period (interviews with various NGOs based in Samarinda and staff at the district forestry office in Melak, Kutai Barat, July 2000). Official statistics were therefore likely to understate real timber production from the area. Growing volumes of timber were expected to come out of the Kutai Barat area in the near future because much of Kutai Kartanegara has already been logged out and badly affected by the 1997-98 forest fires (Hoffmann et al. 1999).

In 1998/99, 22 companies had been granted timber concessions known as Hak Pengusahaan Hutan (HPH) within the Mahakam Ulu region, covering a total 
area of approximately 2.6 million ha. However, by the time that Kutai Barat was established as a kabupaten, there were only 10 active HPH concessions in the region, covering a total area of approximately 1.6 million ha. Most of these companies were operating in the far reaches of the district where there was very little physical infrastructure and few people. Two of the 10 active HPH companies - PT Kemakmuran Berkah Timber and PT Daya Besar Agung — were working together with the state-owned forestry companies, Inhutani I and Inhutani II respectively. In 1998, these $10 \mathrm{HPH}$-holders produced approximately 346000 $\mathrm{m}^{3}$ of logs. This was roughly half of Mahakam Ulu's total annual log production for the year 1997/98 and approximately 15 per cent of Kutai's annual log production.

In addition to these 10 companies, five $\mathrm{HPH}$ companies had requested extensions of their concession licenses and were expected to become active within the next few years (BAPPEDA 1997; Kalimantan Timur 1998b). These five companies were expected to operate over a total area of 442500 ha. Four of these companies were working together with Inhutani I. It is possible that much of this area may also be logged before other districts with high timber potential, such as Berau, because timber originating from the Kutai Barat region can more easily be transported to one of the many mills that line the Mahakam River between Tenggarong and Samarinda.

Seven companies had also been granted concession licenses in Kutai Barat to develop industrial timber estates, or Hutan Tanaman Industri (HTI). Areas allocated to these seven plantation companies covered a total area of 119827 ha (Kalimantan Timur 1998a). Most of these plantations were located in the southeastern region of Kutai Barat. Two of these HTI companies - PT Riau Timas and PT Marimun Timber - were private timber estate companies, which operated independently. The remainder were participants in the government's HTI-Trans program, initiated by the Suharto government to provide employment for transmigrants from Java and other more populated parts of Indonesia. These estates were established on areas formerly managed as HPH timber concessions. Most of the HTI plantation companies were run by timber companies operating in the area; however, PT Alas Cakrawala was managed by Inhutani I. In 2000, only 23914 ha had been planted to timber estates in Kutai Barat, amounting to 20 per cent of the total concession area allocated. Most of the planted area fell within concessions managed by three companies: PT Anangga Pundinusa, PT Hutan Mahligai and PT Kelawit Wana Lestari.

\section{Agro-Industrial Estate Crops}

As of 1999, the three main agro-industrial plantation crops cultivated within the original administrative boundary of Kutai were oil palm (40 164 ha), rubber (33 935 ha) and coconut (20 109 ha) (Kalimantan Timur 1998a). Rubber and coconut are traditional crops and most of the estates were owned and managed 
by smallholders in 1998. In contrast, oil palm estates were a relatively new development, and all of the estates had been established by private companies since 1990 (ibid.). Within the original administrative boundary of Kutai, most oil palm development had occurred in Kutai Timur, followed by Kutai Barat and Kutai Kartanegara. All three regions had ambitious plans to develop the sector and many companies had already received location permits, especially in the districts of Kutai Timur and Kutai Barat. A considerable area of forest land designated for conversion (more than $600000 \mathrm{ha}$ ) had also been released for oil palm development in the district of Kutai Timur. However, little forest land had been released in Kutai Barat or Kutai Kartanegara (Figure 4.3).

In Kutai Barat, there were only three estates in which oil palm had already been planted by 2000: PT London Sumatra International, PT London Sumatra Indonesia and PT Gelora Mahapala. All three of these estates fell under a company known as PT London Sumatra International Tbk (PT LonSum). ${ }^{7}$ PT LonSum had a significant presence in the district and was surrounded by conflict and controversy. The company had established plantations on land belonging to a number of Dayak Benuaq villages located in the Lake Jempang area (Figure 4.3), and it had been heavily criticised by grassroots organisations and NGOs for its alleged association with the 1997-98 forest fires and illegal land clearing; and for its oppressive action against local people (Muliastra et al. 1998; Gönner 1999; Ruwindrijarto et al. 2000; Wakker et al. 2000). Carrying substantial debts since the Asian financial crisis struck in mid-1997, the company's finances have also attracted a lot of interest both nationally and internationally (EIA 1998; Wakker 1999; Wakker et al. 2000).

7 PT London Sumatra was founded in 1906 by a British company, but later became a subsidiary of British palm oil traders Harrisons and Crossfield. Harrisons and Crossfield was established in 1844 as a wholesale dealer in coffee and tea. The company later became active as managing agents and plantation proprietors in Ceylon and Malaysia, and unusually high profit from rubber encouraged further expansion to include Sumatra's East Coast in 1907. Several concessions were then leased in Deli for tea, coffee, rubber and tobacco, and in 1909 operations were extended to Java, where two more subsidiaries were formed. While the exact figures concerning Harrisons and Crossfield's holdings during these early years in the 1920s are unavailable, the company's landholdings were estimated to be around two million acres in Malaya, North Borneo, Indonesia, India, Ceylon and East Africa (Stoler 1985). In the mid-1990s, Harrisons and Crossfield sold its stake in the company and LonSum became an Indonesian company publicly listed on the Jakarta and Surabaya stock exchanges. Shareholders in the company included a number of prominent Indonesians with close connections to the Suharto family, such as Ibrahim Risjid, Andry Pribadi, and Henry Liem. Ibrahim Rashid was also one of the founders of the Salim Group one of Indonesia's largest Chinese-Indonesian owned companies that has close ties to the former Suharto government. He was also the founder and majority shareholder of the Risjadson Group. 


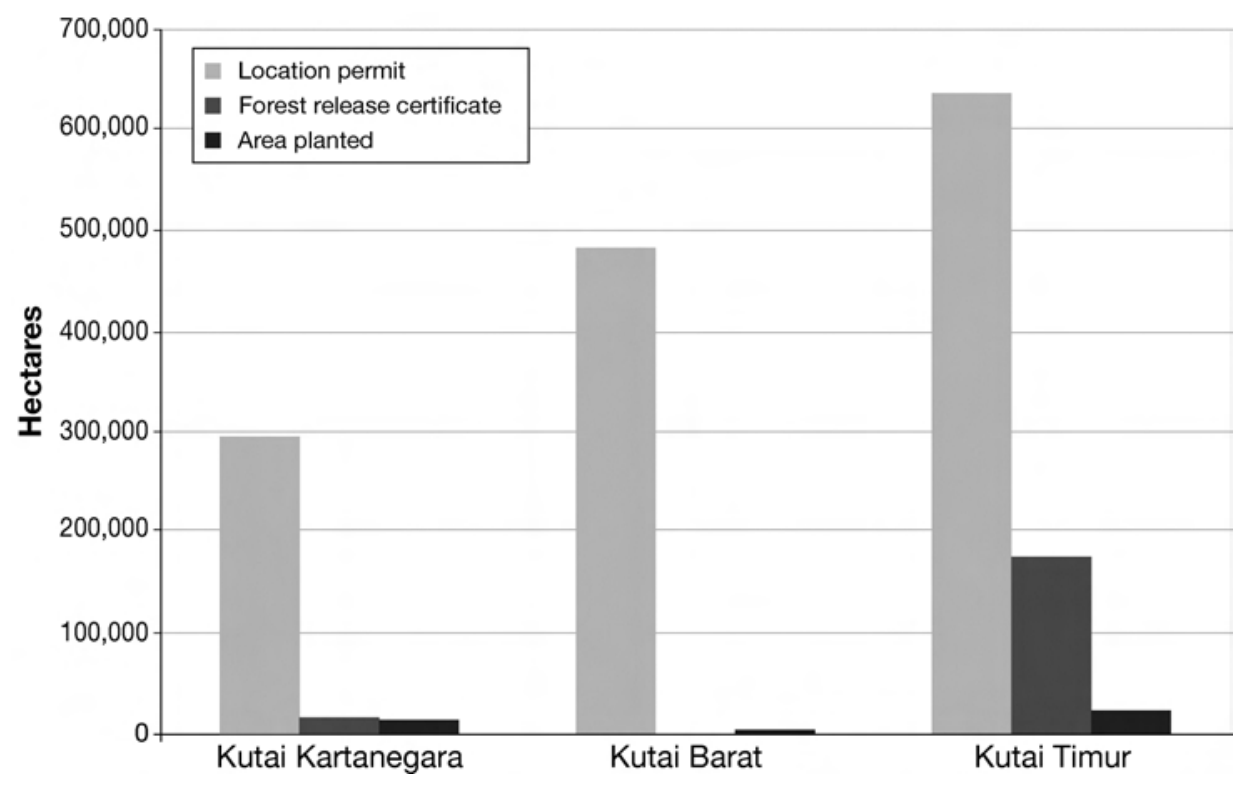

Figure 4.3. Actual and planned oil palm development in Kutai Kartanegara, Kutai Barat and Kutai Timur, March 2000

Source: Kalimantan Timur 1998a; unpublished statistics from the Kutai Kartanegara plantation office

At the beginning of 1998, LonSum management reacted to continuing adverse business conditions by deferring both the construction of a new oil palm mill in South Sumatra and planting activities in South Sumatra and East Kalimantan. In 1998, the company had only planted 99 ha on its new estates because the crisis had reduced the company's internal liquidity. When fieldwork was conducted in the area, the company had stopped all planting operations due to a lack of funding. Community conflict in the area had eased as a consequence, but other elements of the community were suffering. Not only had some local people lost their land to oil palm, but they had also lost any employment opportunities previously being offered by the company. Many had also joined the company's PLASMA scheme in which they had been promised two hectares of oil palm estate. By mid-2000, community members were just starting to realise that there was little chance of this scheme going ahead. Moreover, many of the oil palm trees had already started to bear fruit, but the company had no funds to establish a factory. The fruit was rotting on the ground or being fed to chickens as the nearest factory was in Pasir district, too far away to process oil palm fruit harvested from the LonSum sites. ${ }^{8}$

${ }^{8}$ Palm oil needs to be extracted from oil palm fruit within 24 hours. 


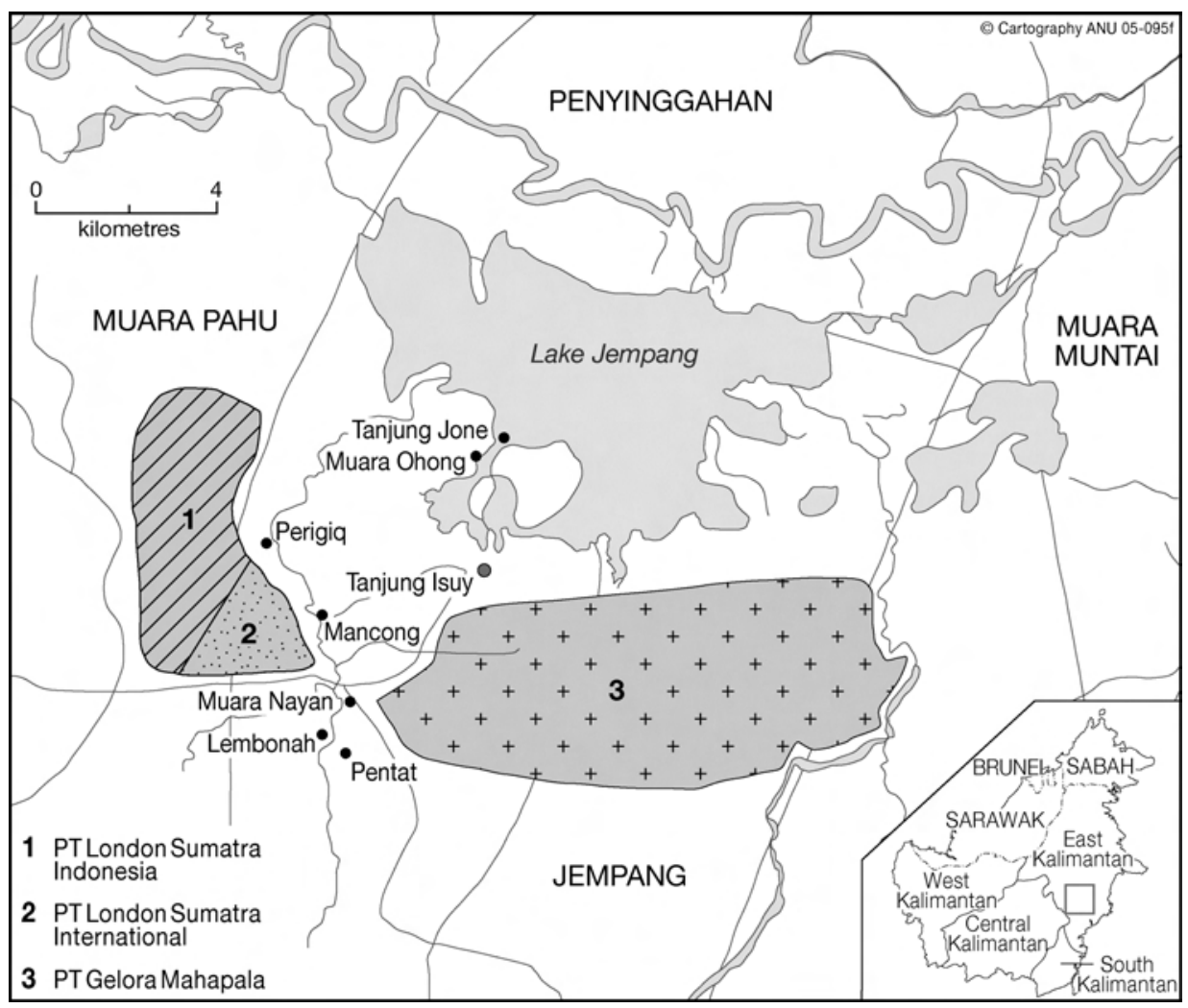

Figure 4.4. Location of villages in the PT London Sumatra Plantation Area, East Kalimantan

Source: Map data from GTZ Sustainable Forest Management Project ${ }^{9}$

\section{Decentralisation in Kutai Barat}

\section{District Finances}

Kutai Barat faces many challenges in the years ahead because it is the least developed region originating from Kutai district. Before the original district of Kutai was divided into three districts, it was the richest region in the province of East Kalimantan. Most of this income came from the district's natural resource base. In fact, Kutai has a long history of natural resource use and extraction. The modern founder of the Kutai sultanate (Sultan Mohammad Sulaiman, 1845-99) had a great talent in commercial activities, leasing out Kutai's lands for coal exploitation and plantations (Magenda 1991). Revenues also came from

9 Official map data on the location of the PT LonSum plantations in the Lake Jempang area do not yet exist because the company has not acquired a number of permits from the Ministry of Forestry and the National Land Agency. The locations of the plantations shown on this map are therefore estimated from a visit to the area. 
taxes levied on forest products transported down the Makaham River and royalties received from coal and plantation activities. Shortly after coal and oil were discovered in the sultanate in the late 1890s, a new sultan (Sultan Alimuddin, 1902-20) had to sign a treaty with the Dutch relinquishing certain rights over taxes. The treaty also stipulated that the Ulu Mahakam area, now known as Kutai Barat, would be governed by the Dutch. With the acquisition of the Ulu Mahakam area, the Dutch were able to control traffic along the Mahakam River and restrict the activities of the Kutai sultanate. With the imposition of these restrictions, the sultan received an annual salary of 25000 guilders in addition to 50 per cent of oil royalties and 10 per cent of forest royalties (Magenda 1991).

During the timber boom of the late 1960s and 1970s, ${ }^{10}$ the Kutai government again benefited from the exploitation of forest resources in the Mahakam region (Manning 1971; Magenda 1991). While the central government profited the most from extensive logging via taxes obtained from the HPH licence fee, a 10 per cent export tax, and a forest product royalty, the Kutai government still received a great deal from their own state-run timber companies (Perusahaan Daerah); as well as from taxes from timber and log pond retribution (Magenda 1991).

Before Kutai was divided into three districts, the district had a regional income of approximately Rp184 billion (or approximately US\$18.4 million) ${ }^{11}$ in 1997/98. This was more than double the income of other districts in the region. For instance, Pasir only had a regional income of approximately Rp68.7 billion, while Berau had a regional income of Rp55.2 billion (Kalimantan Timur 1998a). Since oil and gas were found in Kutai, the district's economy has been largely dominated by the oil and natural gas industry ${ }^{12}$ (42.24 per cent), followed by the forestry and agriculture sector (25.24 per cent), the processing industry sector (13.72 per cent), the building sector (8.55 per cent), and the trade, hotel and restaurant sector (8.25 per cent) (Bupati Kutai 2000).

In light of the above, a considerable percentage of district revenue was generated from taxes obtained from the mining and forestry sectors in the years 1997/98 (Kalimantan Timur 1998a). For instance, Kutai received approximately Rp83.9 billion from the mining sector and Rp26.7 billion from the forestry sector. Again this was more than other districts received over the same period of time: Pasir only received approximately Rp4.6 billion from the forestry sector and Rp12.9 billion from the mining sector in the year 1997/98. Pasir did, however, generate more revenue (Rpl.4 billion) from the plantation sector than Kutai

10 During the 1970s, East Kalimantan produced 30-40 per cent of the nation's timber exports and around two thirds of the total national timber supply (Magenda 1991).

11 Although the Rupiah has fluctuated considerably against the US dollar since mid-1997, an exchange rate of Rp10 000 to the dollar is assumed throughout this chapter.

12 Most of the oil and gas deposits lie within the area now designated as Kutai Kartanegara and Kutai Timur. 
because the majority of the East Kalimantan's plantation estates fell within this district (ibid.).

After Kutai was divided, the provincial government expected Kutai Barat to generate the least revenue in the area because it was the least developed and most isolated region in the Kutai area. A paper released by the Bupati of Kutai Kartanegara shortly after Kutai was divided into three districts projected that Kutai Barat would generate just US\$2.1 million in revenue in 2000, while Kutai Kartanegara and Kutai Timur were expected to generate US\$5.6 million and US\$6.2 million, respectively (Bupati Kutai 2000). This clearly highlighted the financial problems Kutai Barat was expected to experience in the new era of regional autonomy. The district government was also concerned that regionally generated revenues would not be sufficient to establish a new district, capital city and the entire associated infrastructure (personal communication, head of the Regional Development Planning Agency, Kutai Barat branch, July 2000).

Realising this, the governments of Kutai Kartanegara and Kutai Timur pledged to provide Kutai Barat with Rp3 billion in order to finance some of the infrastructure needed to establish a new district. The funds were to be used to establish the necessary government offices as well as the houses for the Bupati, Assistant Bupati, the District Secretary, and heads of district government agencies (Kaltim Post, 16 November 1999).

The local government of Kutai Barat also began to make plans to be fiscally independent. The Bupati was keen to attract new investment to the region and to generate regional income from the district's natural resource base. He was also supportive of existing industries such as PT Kelian Equatorial Mining (PT $\mathrm{KEM})^{13}$ - a large open-cut gold mine located in the sub-district of Long Iram, which had long attracted criticism from national and international NGOs. ${ }^{14}$

PT KEM is one of the largest gold plants constructed in the world and it had the potential to generate substantial revenue for the district. Between 1995 and 2000, the company had paid a total of Rp85 billion to the central government and Rp144 billion to the East Kalimantan provincial government. ${ }^{15}$ Most of this revenue came from corporate income tax and land rent tax. Regional autonomy gave the Kutai Barat government the opportunity to receive a large proportion

\footnotetext{
13 The company is an Indonesian incorporated company, 90 per cent owned by Rio Tinto Ltd and 10 per cent by PT Harita Jayaraya of Indonesia. The Kelian deposit was discovered in 1976 by Rio Tinto's exploration group, but commercial production did not begin until January 1992. Once operational, the mine was producing and exporting an average of 450000 ounces of gold and 400000 ounces of silver per annum.

14 These NGOs have claimed that the mine has a substantial environmental and social impact in the area. Mine by-products are believed to be polluting local waterways and the surrounding environment; and NGOs have claimed that up to 80000 people were forcibly removed from the site and resettled. This has given rise to human rights abuse issues and complicated compensation claims (Down to Earth 1998).

${ }^{15}$ Much of this revenue subsequently went to the central government.
} 
of these taxes. In fact the Bupati had already had several discussions with the mine about how taxes would be distributed between the Kutai Barat government and the provincial and central governments (personal communication, PT KEM management, July 2000). Nevertheless, problems existed because NGOs and some local communities did not support the mine's activities. Revenue generated from the mine was also limited by the fact that the company planned to close down its operations in 2004. The planned closure was causing local government officials and communities much concern as the region only had the potential to benefit from tax payments for two to three years. The district government would then be left with the consequences of the company closing down, unemployment and environmental damage ${ }^{16}$ caused by mining activities.

\section{Creating a District Regulatory Regime to Exploit Forest Resources}

While Kutai Barat had limited infrastructure and revenue it was rich in natural resources, particularly forest resources. Realising that revenue from the PT KEM mine was limited, the local government began to identify ways to facilitate and support local development through forest exploitation shortly after it was formed. According to the Kutai Barat district government, the central government had given district governments some rights to generate revenue from forest resources through the issuance of the new decentralisation laws (No. 22/1999 and No. 25/1999); and Regulation No. 6/99 on Forest Utilisation and Forest Product Harvesting in Production Forests. Following the release of the latter regulation, the Kutai Barat government followed the lead of the Kutai Kartanegara government to issue 100 ha concessions as a means to generate revenue and allow local people to benefit from forest resources. By the end of 2000, the Kutai Barat government had issued 220 Permits to Use and Harvest Timber (Ijin Pemanfaatan dan Pemungutan Kayu) and nearly 50 HPHHs (Forest Product Harvesting Rights). These licences cumulatively covered approximately 22300 ha of forest land and allowed the Kutai Barat government to generate approximately US\$27000 in revenue (Kaltim Post, 24 August 2000). In 2000, the HPHH scheme had gained a lot of support from the general populace, primarily because it was realised that HPHHs could generate substantial revenue for the new district, and also because the allocation of HPHH permits would enable local people to secure a greater share of the benefits from forest resources.

\footnotetext{
16 PT KEM had admitted that it was unable to rehabilitate approximately 950 ha out of the total 1285 ha of forest land disturbed by mining operations. This land would instead be turned into lakes and wetlands after mine closure. To compensate for the land it is unable to rehabilitate, PT KEM is currently planting trees in two replacement areas: Linggau Plateau, which is within the Contract of Work area, and Bukit Suharto, north of Balikpapan. Around 5700 ha of forest land remain intact in the concession area, and the PT KEM management group hoped that its status could be changed to 'Protected Forest' area after the mine closed (personal communication with PT KEM management, July 2000).
} 
However, a number of problems were also noted. For instance, it was recognised that there was potential for local people to be exploited through the process, particularly as they were dependent on outside partners for capital and machinery. Local government also lacked the capacity to ensure that forest exploitation was carried out in a sustainable and equitable manner. The small-scale licences were undoubtedly fuelling an increase in deforestation and little thought had been given to forest rehabilitation or reforestation. Consequently, the Mahakam River was flooded with timber (dibanjiri kayu) from the region - one woman interviewed along the Mahakam River between Tenggarong and Samarinda said she had not seen so much timber pass through the region since the 1970s.

Donors and non-government organisations raised a number of concerns about the issuance of these new permits. They raised concerns about the potential for HPHHs to increase conflict among communities and individuals - especially since many of the permits were being allocated in HPH concessions, HPHH rights could be manipulated by government officials and outside interests, and their issuance could give negative connotations to the decentralisation process.

The timber industry also raised concerns about the fact that HPHHs were being issued within existing $\mathrm{HPH}$ concessions, and this was a matter of concern to provincial and central governments as both were under significant pressure from the timber industry to restore law and order in the forest estate. For instance, in early 2000, 77 loggers in Kutai and Bulungan threatened to close down their operations if local and provincial governments did not prevent local people from logging their concessions and disrupting their activities (Jakarta Post, 21 February 2000). The Association of Indonesian Timber Concession Holders (Asosiasi Pengusaha Hutan Indonesia) also complained that several companies in Kutai and Bulungan were unable to continue operating as local peoples had seized their heavy equipment to demand payments amounting to billions of rupiah (Jakarta Post, 21 February 2000: 9). Moreover, in February 2000, some 10 foreign investors and plywood buyers, mainly from South Korea, threatened to pull out of their contracts due to concern over escalating conflicts between timber companies and local people. The buyers said that they were worried that plywood mills would not be able to meet delivery schedules as many timber companies had stopped logging operations as a result of prolonged disputes with local people (ibid.).

In early 2000, the central government realised that it had lost control over the allocation of $\mathrm{HPHH}$ permits and was losing large amounts of potential revenue from district timber regions. The Ministry of Forestry and Estate Crops then suspended its earlier regulation giving district governments the right to allocate small-scale logging permits. Both the Bupati of Kutai Kartanegara and Kutai Barat were ignoring this decision and arguing that, under regional autonomy, they 
were duty bound to ensure that local people would directly benefit from forest resources (personal communication, Bupati of Kutai Barat and Kutai Kartanegara, 5 August 2000).

\section{A New Forestry Vision - Community Forestry}

Heeding the concerns raised by the forest industry, donors and local non-government organisations, the newly elected Bupati, Rama Alexander Asia, eventually decided to slow down the issuance of HPHH licences in 2001. He also solicited assistance from organisations such as the USAID-funded Natural Resource Management Project, the GTZ Sustainable Forest Management Project, the International Centre for Research on Agroforestry, and local NGOs such as PLASMA and Puti Jaji, to develop a more sustainable model of community-based forest management in the area.

In November 2000, a West Kutai Regional Forestry Program Working Group (Kelompok Kerja Program Kehutanan Daerah or KKPKD) was formed with assistance from the Natural Resource Management Project. Representing a diverse set of local forest sector stakeholders including government officials, adat or customary rights leaders, community representatives, NGOs, university professors and the private sector, KKPKD sought to understand the complexities of forest management in West Kutai District and to develop transparent and accountable management strategies for balancing sustainable forest management and improved community welfare in a participatory manner. In recognition of the importance of KKPKD's work in terms of good governance and sustainable forest management, the Bupati of West Kutai formalised this working group on 2 January 2001 with Decree No. 453/K.065/2001. This provided a clear mandate for KKPKD 'to establish a viable forestry program involving forestry-related activities and stakeholders in West Kutai District' (KKPKD 2001).

Over the course of 2001, KKPKD worked through a number of planning activities in a wide range of formal and informal workshops and meetings, both large and small, to first understand forest management issues and to then develop a realistic forest management plan. While these major activities were being carried out, KKPKD also sought to make the results transparent to the general public. Innovative public consultation processes and regular use of electronic media - particularly radio — kept the public informed and involved (KKPKD 2001).

The West Kutai District Forest Management Plan was divided into seven main themes: forest recovery and management, institutional development, law enforcement, infrastructure, regional policy development, recognition and empowerment of adat customary and community rights, and human resource development. Within these seven main themes, 52 specific activities were presented and ranked in terms of their relative priority and targeted for 
completion within the next ten years. The plan also included information on supporting institutions and their roles, time frames, resources, basic assumptions, expected results, and criteria for the success for each activity (KKPKD 2001).

In 2002, two important regional or district regulations (Peraturan Daerah or Perda) were developed in accordance with this plan - Regulation No. 18/2002 on forestry and a draft regulation on the implementation of community forestry in the district. The regulation on forestry, which was signed by the Bupati on 4 November, provided the umbrella framework for all forestry matters in the district, including community forestry. Article 9 of this regulation stated that the local government would recognise and gazette customary forest (adat) areas. It also stated that the local government would allow local people to manage forest resources in accordance with their customary rules and regulations. To strengthen this point, an entire chapter (Chapter 5) was devoted to the rights and roles of local people in local forestry matters. Forest planning was to be carried out in a transparent, participatory, accountable, integrated fashion, which allowed for community aspirations (Article 13); and local people would be kept well informed about large-scale forest exploitation (Article 18). The participation of local people in conservation and forest rehabilitation was also stressed in Articles 28 and 43.

The draft regulation on community forestry further strengthened the local government's intent to recognise and legitimate customary forest management systems. Article 2 of this regulation stipulated that the government would respect and recognise local communities that carried out forest management in an equitable and sustainable manner. If this is proven to be so, the government will recognise various types of community forestry, including customary forest management, village forest management, and local conservation efforts (Article 3). In order for the local government to grant a right to carry out community forestry, the designated area must be proven to be free from conflict and already covered by internal regulations which sustain forest resources (Article 7). If granted a community forestry licence, the community is obligated to sustainably manage forest resources in a just and equitable fashion (Article 23).

However, while both of these regulations promote more equitable forest exploitation, several articles contradict central government regulations and could be considered to be illegal. For instance, in the regulation on forestry, the Bupati retains the sole right to issue licences for timber collection, community forestry, forest use by the wood industry, non-timber forest product collection, and the use of environmental services (Article 34). This article contradicts two key central government regulations - Regulation No. 34/2002 on Forest Planning, Management and Use (the long awaited clarifying legislation of the Basic Forestry Law No. 41/1999) and Decree No. 31/2001 on Community Forestry. The regulation 
and the decree both stipulate that the Bupati can only issue these permits after he has sought approval from the Ministry of Forestry.

Similarly, in the draft regional regulation on community forestry, the Bupati retained the sole right to issue a 'Community Forestry Permit' (Izin Kehutanan Masyarakat) after he received a recommendation from the head of the District Forest Department (Article 6). This contradicted Decree No. 31/2001 which stipulates that the Bupati can only recommend that a 'Community Forestry Activity Permit' (Izin Kegiatan Hutan Kemasyarakatan) be allocated after he has sought permission from the Ministry of Forestry through the Provincial Governor. More significantly perhaps, the draft regulation specified that a Community Forestry Permit could be allocated for a period of 100 years (Article 19). However, Decree No. 31/2001 states that a Community Forestry Permit can only be allocated for 25 years. Given the above legislative contradictions, the Kutai Barat government needed to gain broad political support for district government regulations pertaining to forestry in order to avoid conflict with the central government, and to gain its support for their future forest management plans.

\section{Decentralisation and the Oil Palm Sub-Sector}

When fieldwork was undertaken in mid-2000, the local governments of Kutai Kartanegara and Kutai Barat were keen to develop the oil palm sub-sector as they saw it as a potential revenue generator. However, they were becoming increasingly frustrated with the central government, which implemented a moratorium on further forest conversion for plantation development in 1998 (Casson 2000). At a meeting held in Samarinda, the Assistant Head of East Kalimantan's Provincial Legislative Assembly publicly stated that provincial and district governments would no longer allow the central government to limit their ability to establish and promote further oil palm developments in the area:

If the government continues to insist that they will not give out forest release permits to companies or communities in East Kalimantan, then the Kutai government is ready to seize them (translated from Kaltim Post, 1 May 2000).

He then went on to say that carrying out autonomy in the current era of globalisation is a great opportunity for East Kalimantan to move forward and open one million hectares of forest land for plantations, be it oil palm or other crops (ibid.).

In order to open one million hectares for plantation development, the Assistant Head of the East Kalimantan Legislative Assembly said that the provincial and district governments would seize control of forest release permits in order to facilitate development. He further said that they would legitimise this process by issuing their own legislation on the release of forest land for plantation development (Kaltim Post, 1 May 2000). The Bupati of Kutai Kartanegara was 
very supportive of these actions, stating that there were over 200 entrepreneurs waiting to invest in the sector. Many of these entrepreneurs were said to be from overseas countries, including Germany, Japan, Korea, Singapore and Malaysia (Kaltim Post, 28 July 2000).

To facilitate the development of oil palm plantations in the area, the National Land Agency (Badan Pertanahan Nasional) at both the provincial level and Kutai Kartanegara district level had discussed ways in which they could speed up the allocation of permits for oil palm estates. During an interview, the head of the provincial office of the National Land Agency explained that his office planned to lobby the provincial assembly to pass legislation that would enable them to issue location permits and land-use rights. Forest release permits would pass through the Dinas Kehutanan office at the district and provincial levels to the Governor of East Kalimantan. It was hoped that the Governor would be given the authority to release forest land in the province and pass on his recommendation to central government. By cutting the central government out of the permit-allocation process, the provincial and district governments expected to be able to accelerate oil palm development and forest conversion. At the time, the central government appeared to be willing to accommodate these plans, as a meeting was held in March 2001 between the National Land Agency and the National Development Planning Agency (Badan Perencanaan Pembangunan Nasional) to review the 1960 Agrarian Law in an attempt to simplify the permit-allocation process for potential investors (Jakarta Post, 2 March 2001). According to the provincial head of the National Land Agency potential investors were optimistic about these plans and eagerly awaited their implementation (personal communication, August 2000).

The Kutai Barat district government also wished to facilitate further oil palm development, but it was concerned about the fact that PT LonSum had failed to build a palm oil processing plant and had stopped further planting in the area. The district government was also aware that conflict surrounding PT LonSum's plantations was deterring other investors from developing oil palm plantations in the region. In order to attract investment, the district government was trying to secure the company's land use permit and to support the establishment of a palm oil processing factory (personal communication, Kutai Barat District Government Secretary, 28 July 2000). While it looked certain that the land use permit would soon be issued, it seemed unlikely that LonSum would be able to establish a factory or resume planting in the near future.

The Bupati of Kutai Barat was of the opinion that problems arising from the LonSum development were a consequence of central government control over the licensing procedures. He felt that the central government did not adequately consult or inform the local people about the company's development plans and that this had resulted in a number of misunderstandings which led to conflict 
and the occupation of the base camp. He was confident that decentralisation could provide district governments with the opportunity to better manage conflict with local communities because they would be more responsive to local needs and more aware of problems arising from such developments. He also felt that local government would better understand the concerns of local communities and be more able to accommodate these concerns into development plans (personal communication, Bupati Rama Asia, July 2000).

A number of international donor organisations and local NGOs held a similar opinion. Most thought that decentralisation had the potential to allow a lot more community consultation and participation in local government decision making. They were of the opinion that the central government had proved that it could not manage natural resources sustainably, and they were confident that decentralisation could improve the situation if implemented in a manner that supports good governance (Usher 2000). Many of the Samarinda and Balikpapan NGOs had committed themselves to helping the Kutai Barat government to build up their expertise, skills, knowledge and revenue (GTZ 2000). Some, such as Plasma, were also helping the district government to draw up district regulations. It remains to be seen if the local government of Kutai Barat has the skills and expertise to manage natural resources. There is always the danger that the Kutai Barat government will speed up the forest conversion process in order to facilitate further oil palm development and generate much-needed district revenue.

\section{Conclusion}

In Kutai Barat, decentralisation has the potential to build up the physical infrastructure and industrial facilities of the district. Before Kutai was divided into three regions, most of the original districts development occurred within the area now encompassed by the district of Kutai Kartanegara, while the outer regions of Kutai Barat were more or less neglected. Following the partition of Kutai, the Kutai Barat government has the opportunity to focus on developing these previously neglected areas and ensuring that more funds are directed to building up local infrastructure. A Kutai Barat government is also likely to pay more attention to local people and to listen to the needs and concerns of the local population.

However, the Kutai Barat government faces many challenges in the years ahead as it has to work with limited infrastructure, poorly skilled government officials and little revenue. PT KEM planned to close down its operations in 2004 and PT LonSum had limited funds to continue its operations and build a crude palm oil processing factory. Because of this situation, the local government was being forced to find new ways of generating income from its natural resource base, particularly forest resources. An example of this was the new HPHH scheme that enabled local government to generate income and local communities to benefit from the district's forest resource base. While this scheme may have 
been preferable to the former system whereby large HPH timber concessions were issued to conglomerates close to the Suharto family, the allocation of large numbers of HPHH permits resulted in increased social conflict and environmental damage. This was primarily because Kutai Barat's district government did not have the skills, staff or expertise to manage or monitor the scheme in 2000.

In 2001, the Bupati of Kutai Barat heeded concerns raised about HPHH licences by NGOs and donors. The Kutai Barat government slowed down the issuance of these permits and decided to develop more transparent and accountable management strategies for balancing sustainable forest management with improved community welfare. These strategies sought to facilitate and develop community forestry mechanisms in order to promote more equitable forest resource exploitation. Nevertheless, problems did exist because district regulations formalising these new arrangements contradicted various central government forest regulations. Agreements between both levels of government were therefore needed to ensure that local government regulations promoting more equitable sharing of forest resources could be implemented and accepted by multiple stakeholders.

\section{References}

BAPPEDA (Badan Perencanaan Pembangunanan Daerah). 1997. 'Data Pokok Pembangunan Daerah Kabupaten Daerah Tingkat II Kutai Tahun 1996/1997 [Basic Data on the Development of the Level II District, Kutai, for the Year 1996/1997].'

Bock, C., 1985 (1881). The Head-Hunters of Borneo: A Narrative of Travel up the Mahakam and down the Barito, also Journeys in Sumatra. Singapore: Oxford University Press.

Brookfield, H., L. Potter and Y. Byron, 1995. In Place of the Forest: Environmental and Socio-economic Transformation in Borneo and the Eastern Malay Peninsula. Tokyo: United Nations University Press.

Bupati Kutai, 2000. 'Paparan Bupati KDH Tingkat II Kutai Tentang Pemekaran Wilayah Kabupaten dati II Kutai Menjadi 3 (Tiga) Kabupaten dan 1 (Satu) Kota [The Explanation of the District Head of Kutai Concerning the Subdivision of Kutai to become Three Districts and One Town].' Samarinda: Bupati Kutai.

Casson, A., 2000. 'The Hesitant Boom: Indonesia's Oil Palm Sub-sector in an Era of Economic Crisis and Political Change.' Bogor: Centre for International Forestry Research (Occasional Paper 29).

Down to Earth, 1998. 'PT KEM Community Demands.'Viewed 1 March 2006 at http://www.gn.apc.org/dte/Cklcd.htm 
EIA (Environmental Investigation Agency), 1998. The Politics of Extinction: The Orang-Utan Crisis: The Destruction of Indonesia's Forests. London: EIA.

Gönner, C., 1999. 'Causes and Effects of Forest Fires: A Case Study from a Sub-district in East Kalimantan, Indonesia.' Draft paper for the ICRAF methodology workshop on 'Environmental Services and Land Use Change: Bridging the Gap between Policy and Research in Southeast Asia', Chiang Mai, 31 May-2 June.

GTZ (Gesellschaft für Technische Zusammenarbeit), 2000. 'Paparan Ketua BAPPEDA Kabupaten Kutai Barat di Rio Tinto Bingung Baru [The explanation of the Head of BAPPEDA, West Kutai district regarding new confusions at Rio Tinto].' Paper presented to a planning workshop, Samarinda, 24 March.

Hoffmann, A., A. Hinrichs and F. Siegert, 1999. 'Fire Damage in East Kalimantan in 1997/98 Related to Land Use and Vegetation Classes: Satellite Radar Inventory Results and Proposal for Further Actions.' Samarinda: Ministry of Forestry and Estate Crops, GTZ and KfW (IFFM-SFMP Report 1a).

Kalimantan Timur, 1998a. 'Kalimantan Timur Dalam Angka [East Kalimantan in Figures].' Samarinda: Kantor Satistik [Provincial Statistical Office].

, 1998b. 'Pemutahiran Data: Pengusahaan Hutan Tahun 1997/1998 [Corrected Data: Forest Companies for the Year 1997/98].' Samarinda: Kantor Wilayah Propinsi Kaltim [East Kalimantan Regional Office].

_ 1999. 'Dinas Kehutanan Dalam Angka Tahun 1998/99 [The Department of Forestry in Figures, 1998/99].' Samarinda: Propinsi Daerah Tingkat i Kalimantan Timur, Dinas Kehutanan [Government of the Province of East Kalimantan, Department of Forestry].

KKPKD (Kelompok Kerja Program Kehutanan Daerah), 2001. 'Program Kehutanan Kabupaten Kutai Barat [Forestry Program for the District of West Kutai].' Melak: KKPKD.

Magenda, B., 1991. East Kalimantan: The Decline of Commercial Aristocracy. Ithaca (NY): Cornell University.

Manning, C., 1971. 'The Timber Boom with Special Reference to East Kalimantan.' Bulletin of Indonesian Economic Studies 7(3): 30-60.

Muliastra, K., F. Rahmadani, S. Kasyanto, H. Suryani, 1998. 'Laporan Survey Kebakaran Hutan di Kalimantan Timur [Survey Report on the Forest Fires in East Kalimantan].' Jakarta: Report prepared for WWF Indonesia Program.

Potter, L., 1990. 'Forest Classification, Policy and Land-Use Planning in Kalimantan.' Borneo Review 1(1): 91-128. 
Ruwindrijarto, A., C. Kirana, H. Pandito, H.R. Effendi, M. Minangsari, F. Ganswira, R.R. Sigit and R. Ranaq, 2000. 'Planting Disaster: Biodiversity, Social Economy and Human Right Issues in Large-scale Oil Palm Plantations in Indonesia.' Jakarta: Telapak, Madanika, Puti Jaji.

Stoler, A., 1985. Capitalism and Confrontation in Sumatra's Plantation Belt, 1970-1979. Michigan: University of Michigan Press.

Usher, G., 2000. 'Why Donors Should Concentrate their Programs at the Kabupaten Level, or Why Focusing Donor Support at the Kabupaten Level is More Likely to Achieve Better Natural Resource Management.' Samarinda: East Kalimantan Natural Resource Management Project.

Wakker, E., 1999. Forest Fires and the Expansion of Indonesia's Oil Palm Plantations. Jakarta: WWF Indonesia.

, Telapak Sawit Research Team and J.W. van Gelder, 2000. ‘Funding Forest Destruction: The Involvement of Dutch Banks in the Financing of Oil Palm Plantations in Indonesia.' Amsterdam: Report for Greenpeace Netherlands. 